\title{
Mukula (rosewood) trade between China and Zambia
}

Paolo O. Cerutti, Davison J. Gumbo, Kaala B. Moombe, George Schoneveld, Robert Nasi, Nils Bourland and Xiaoxue Weng

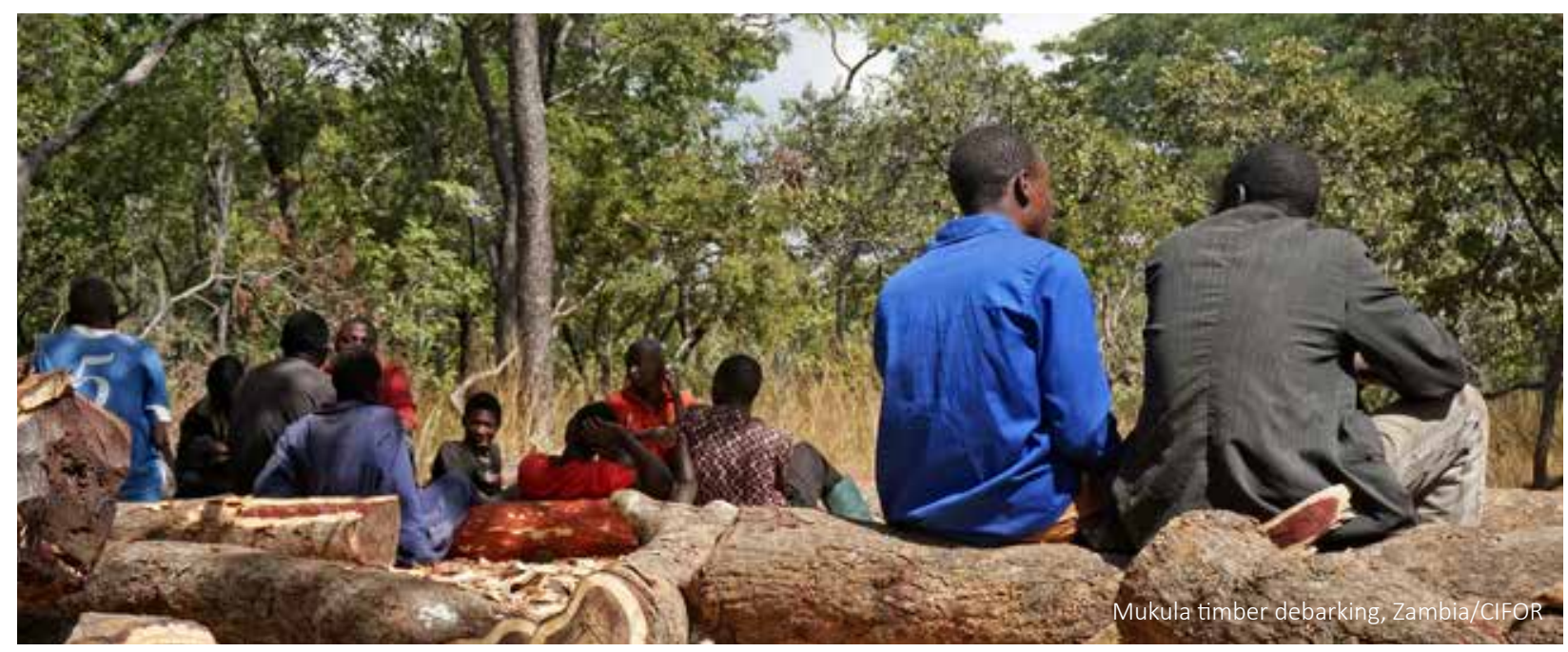

\section{Key messages}

- Despite the existence of clear legal regulations governing the forest sector in Zambia, a peculiar value chain has developed in recent years around highly valuable trees, which are sold mainly on the Chinese market under the general name of 'rosewood' and known in Zambia as 'mukula'.

- The Zambian government has acted on the value chain with a cycle of log-export, production and transportation bans, always short-lived and of ambiguous juridical value, creating a confusing and at times conflicting legal framework. This has allowed the Zambian political and financial elites to maintain power over the mukula trade and use it as a direct and private source of revenue. However, it has also deterred investors from engaging in long-term sustainable timber businesses.

- The mukula trade provides rural community members and cutters with significant — albeit mainly short-term livelihood benefits and business opportunities, despite decreasing profitability and declining stocks over the years and risks of criminalization and prosecution.

- The value chain has several potential negative environmental impacts. More research is needed on the Pterocarpus genus to clarify the botanical characteristics of what goes under the name 'mukula' and to determine the broader impacts on the delicate miombo ecosystem.

- In the short term, one possible solution is listing of the concerned species in the Convention on International Trade in Endangered Species of Wild Fauna and Flora (CITES).

- In the longer term, more integrated supra-national solutions are urgently needed. Existing national laws are insufficient instruments to rein in business models that are fast-spreading, spatially disconnected and capitalintensive. The Zambian government must step up to the task of protecting the Zambian forests and people's long-term livelihoods, by testing and implementing the innovative measures included in the Forests Act of 2015, including community, joint and private forest management. 


\section{Background}

In much of sub-Saharan Africa (SSA), the informal economy rules supreme. Often defined as 'unregulated production, distribution and service provision', informal economic activities across SSA provide crucial cash income and employment for both rural and urban populations. Governing the informal economy is a key policy challenge for governments across SSA, owing to (i) its contribution to local livelihoods, and (ii) its common association with illegality, tax evasion and negative environmental impacts. Because of the increasingly globalized trade in commodities, global sources of capital can also support parts of the local informal economy. Zambia is no exception to these trends.

This Infobrief reports the findings of an assessment conducted in 2016 and 2017. It discusses how Zambia may better address the trade-offs involved in governing an informal economic activity that supports rural livelihoods, very likely harms its forest resources, and presents significant opportunities both for fiscal revenue and rent-seeking behaviors. To illustrate the links between global capital - particularly of Chinese origin in Zambia - and its impacts on rural livelihoods, the environment and resource governance, we focus on the international trade in rosewood, or 'mukula' as the traded timber is known in the Zambian context. Quotation marks are used here to highlight that, although in the Zambian regulations mukula does appear as Pterocarpus chrysothrix or P. tinctorius (which is not included in the Chinese official list of rosewood species), there is no agreement about whether mukula refers to a single species or to more species. In fact, the look-alike factor is common and could play a role in the general uncertainty about mukula (Cunningham 2016).

In recent years, mukula has been widely harvested, traded and exported out of Zambia, and has stirred media, civil society, private sector and government attention alike. It fetches very high prices in China and is part of a wider rosewood trade that affects much of Southeast Asia and parts of Africa and South America (Huang and Sun 2013). China imports large amounts of dark-red tropical hardwood species in the form of logs to make hongmu (literal translation: red-wood) antique furniture. Used historically by the imperial elite, hongmu is now coveted by the rising middle class.

Because of this international dimension of trade, and the push and pull factors that global capital may play on Zambia's regulations and resource governance, mukula is an ideal illustration of the production and trade of one commodity which can theoretically be tightly regulated and traded within the formal economy, and yet it is almost entirely nested in the informal one (Puustjärvi et al. 2005; FEVCO 2007; Lwaile and Gumbo 2016).

The political and technical factors that result in the vast majority of production remaining informal were discussed in a series of workshops with government officials; in 266 one-to-one interviews with cutters, brokers, buyers and key informants; and in 52 focus groups across 29 villages in 4 districts, with a total of 494 participants. This Infobrief lists the major results of those discussions and suggests policy options to improve the value chain, broaden its positive impacts and decrease the negative ones.

\section{Major findings and policy options}

\section{Finding 1: High volumes of mukula continue to be exported as logs despite regulations prohibiting it.}

Recent mukula production in Zambia could have amounted to about $110,000 \mathrm{~m}^{3}$ per annum, with revenue losses of about USD 3.2 million and bribes paid to state officials of about USD 1.7 million. While official statistics remain incomplete and unclear, comparing Zambia and Chinese customs data reveals significant differences. Figure 1 and Figure 2 compare export statistics for logs and sawnwood as declared by Zambia to the Food and Agriculture Organization of the United Nations (FAO), with data from Chinese customs.

The two figures illustrate important features of the evolution of the mukula value chain over recent years.

First, what leaves Zambia as sawnwood seems to arrive in China as logs. It seems clear that mukula, which is largely exported in logs, often gets declared as sawnwood at departure to comply with the legal framework, as a log-export ban remains in force in Zambia.

Second, the 'mukula effect' is clearly visible starting with the 2014 declarations from the Chinese Customs for logs imported

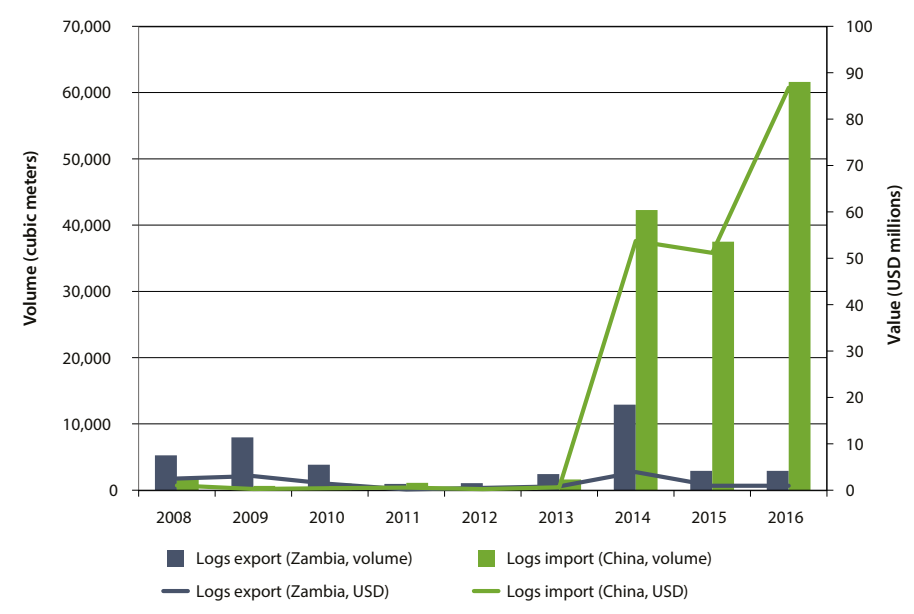

Figure 1. Logs export and import (2008-2016, FAOSTAT and Chinese Customs data) 


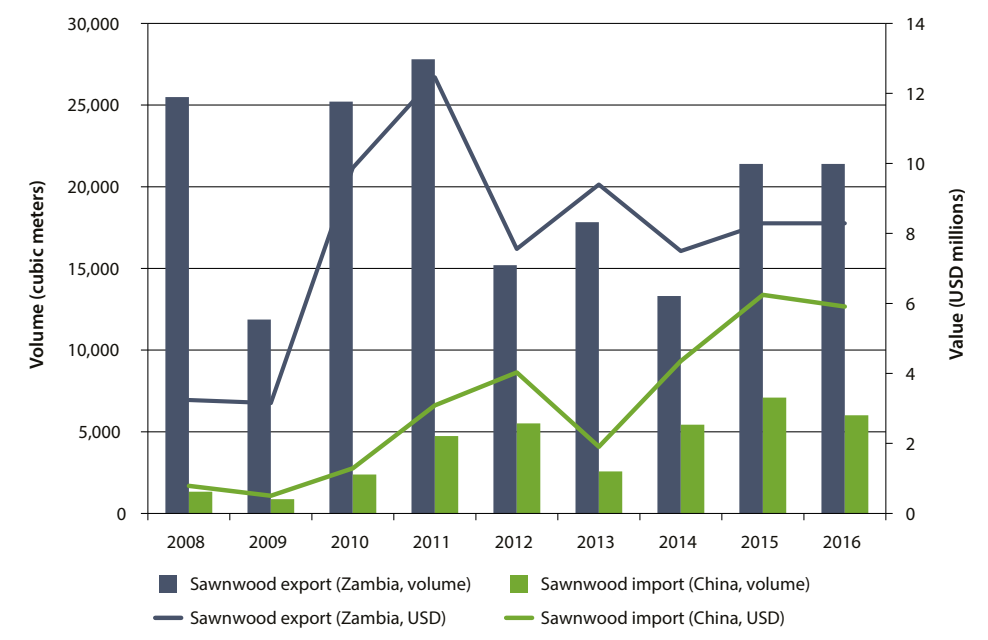

Figure 2. Sawnwood export and import (2008-2016, FAOSTAT and Chinese Customs data)

from Zambia, both in volume and value. For example, in 2016, Zambia declared to have exported about 3,000 $\mathrm{m}^{3}$ for an approximate value of USD 900,000, while China declared imports of about $61,000 \mathrm{~m}^{3}$ for an approximate value of USD 87 million.

Recommendation: The log-export ban should be lifted because mukula logs are being exported in other ways, both legally and illegally, depriving the state of potential revenues. The Forestry Department should propose a revision of the legal framework for appropriate taxation to be applied to exported logs.

Recommendation: The Forestry Department, Customs and Zambia Revenue Authority should consider conducting regular comparative assessments with Chinese Customs, to monitor large inconsistencies in trade data and apply appropriate measures.

Recommendation: The export permits issued by the Forestry Department should be aligned with the tariff codes and timber specifications used by the Zambia Revenue Authority.

Recommendation: The Chinese Customs should monitor large inconsistencies in the trade data, carry out more frequent spot inspections of containers carrying timber imports from Zambia, and collaborate with Zambian counterparts to harmonize data specifications and explore ways to share trade data in real time for verification.

Recommendation: China's State Forestry Administration should encourage Chinese importers to abide by the official Guidelines'

1 In 2007, the State Forestry Administration (SFA) and the Ministry of Commerce (MOFCOM) issued the Guide on Sustainable Overseas Silviculture by Chinese Enterprises. This was followed in 2009 by the Guide on Sustainable Overseas Forest Management and Utilization by Chinese Enterprises. The organizations are also drafting a third guide: Guide on Sustainable Overseas Forest Products Trade and Investment by Chinese Enterprises (Cook et al. 2018). by conducting due diligence on legality and sustainability for tropical timber imports, including on mukula and other related species from Zambia and its neighboring countries.

Recommendation: China's State Forestry Administration should consider the legal and environmental risks embedded in the mukula trade in its future international timber trade policy making, including exploring the usefulness of legally-binding import measures over tropical timber.

\section{Finding 2: Positive short-term benefits for rural livelihoods with questionable long-term consequences.}

The mukula trade boomed around 2010-2012 and has continued ever since. Initially, buyers (largely of Chinese origin) would roam rural Zambia asking people to cut and collect as many logs as they could find. High demand met with harsh rural living conditions, and soon cutting replaced farming as the most important source of income for farmers-turned-loggers (Figure 3).

Farming activities were not completely abandoned. Rather, women, children and friends were in many cases called upon to replace absentee farmers who would spend months in the forests looking for mukula trees. The money earned through harvesting served to support school fees, pay for medicines, buy food and house assets and bicycles, telephones, solar panels and livestock.

The impacts of the increasing mukula trade have trickled down to rural villagers across Zambia. They have forged direct links with foreign investors, earning crucial cash incomes and producing innovative business models that accelerate the rate of small-scale production and extraction of resources. At the same time, they remain embedded in the rural economic system characterized by legal ambiguity and limited government oversight. As a consequence, despite the short-term benefits, such models repeat historical patterns of exploitation. Specifically, while local cutters receive an average price of about USD 23 per cubic meter of timber harvested, manufacturers in China pay about USD 1,000-1,100 per cubic meter to importers, before any further processing on the exported logs.

Recommendation: The Forestry Department should conduct quarterly market surveys on the average international price of valuable commercial species, including mukula, and regularly disseminate them to its decentralized units (notably Provincial and District Forest Officers).

Recommendation: District Forest Officers should regularly display, e.g. in the form of public notices, lists of commercial species with their average domestic and international prices. Concurrently, the Forestry Department should initiate discussions with the Zambia Revenue Authority on a revenue- 

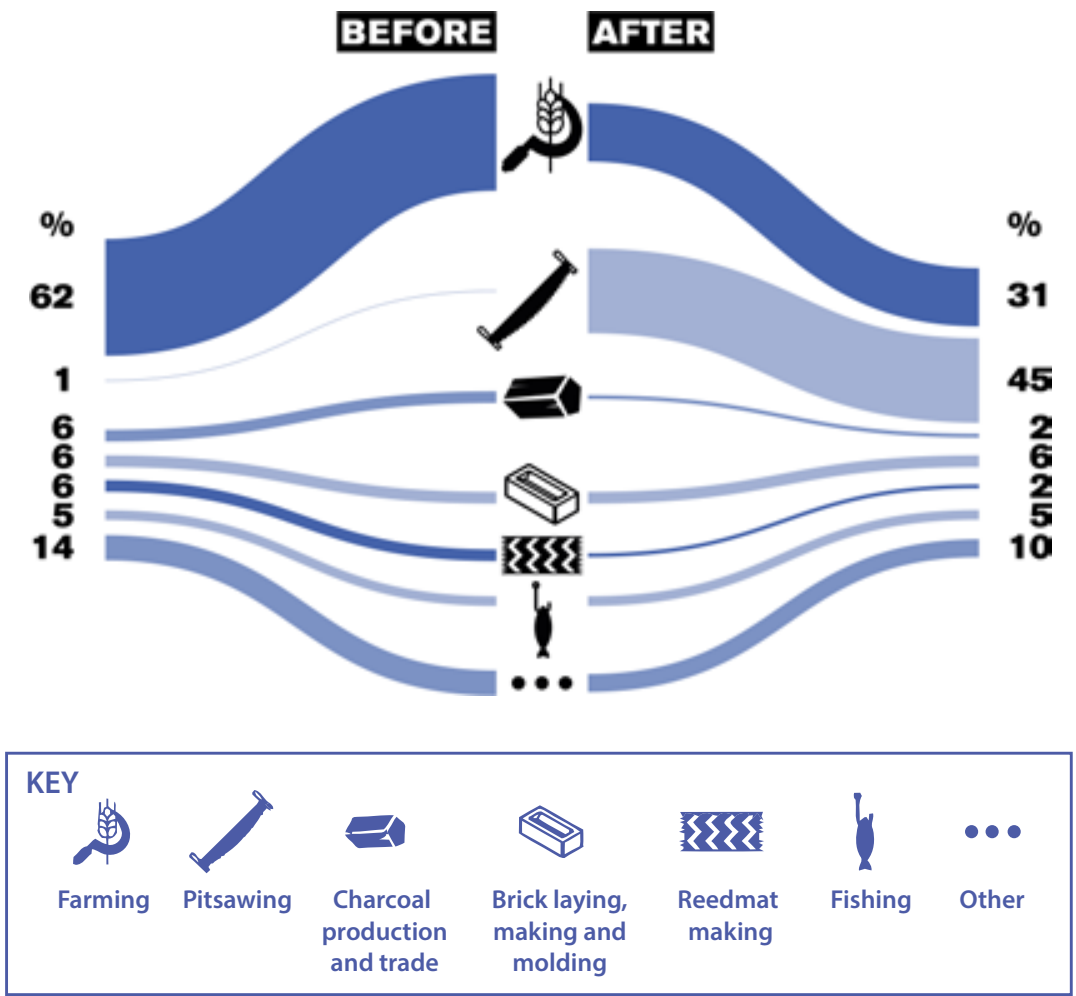

Figure 3. Farmers' activities before and after entering the mukula value chain

sharing scheme to increase financial resources available to provincial and district offices, as well as the number of monitoring and verification missions in harvesting sites.

Recommendation: Given a long history of failures with the business model of logging concessions, the Zambian government must step up to protect the country's forests and people's long-term livelihoods. This would entail implementing innovative measures in the Forests Act of 2015, including community, joint and private forest management.

Recommendation: The Forestry Department should enable communities to benefit from the mukula trade as per framework used in the wildlife sector in Zambia. Where feasible, timber production and trade should be considered as a community enterprise, as provided for under the Forests Act of 2015 and the Community Forest Management regulations SI 11/2018.

\section{Finding 3: Significant environmental risks are not effectively considered in policy making.}

Given the speed at which trade has been developing, it is difficult to assess the long-term environmental impacts of current mukula harvesting operations. Further research is needed on this front. Yet, several findings do indicate potential environmental problems linked to the speed and scale of operations over the past 5-7 years. For example, awareness of any environmental regulations is low among cutters. Only
$6 \%$ of cutters was found to be harvesting trees at the legally established distance of $50 \mathrm{~m}$ or more from a river. Just $4 \%$ of cutters seem to be aware of a legally established buffer zone around rivers, but declare it to be anywhere between $2 \mathrm{~m}$ and $40 \mathrm{~m}$ (i.e. short of the legal minimum limit of $50 \mathrm{~m}$ ). About $90 \%$ of cutters do not seem to be aware that such a limit (and thus the regulation that establishes it) exists.

These data point to potential negative environmental impacts; this project did not assess long-term environmental conditions on harvesting sites. That said, it is troubling that, in addition to operators not generally knowing or respecting the most basic environmental regulations, nobody seems to officially monitor harvesting activities. Indeed, the only reported 'verification' is at the loading bay, where the log's diameter and length are checked. This is done for payment purposes, and clearly not to verify whether environmental or sustainability criteria, or the origin of the log, have been respected.

This lack of monitoring is caused chiefly by the significant resource and capacity constraints of the Forestry Department. The officially mandated government authority to manage the forests is not empowered to do so. Therefore, across time and along the chain, politics, vested interests and elite capture have left little space for environmental concerns regarding the sustainability of mukula production - or any other species for that matter. Importantly, these concerns must not only be linked to mukula or look-alike species, but also to the broader impacts 
on the delicate miombo ecosystem and its structure, soil and fauna when deprived of a locally abundant species or group of species.

Recommendation: The Forestry Department should conduct an inventory of mukula, aimed at improving general knowledge of the species, notably its presence and distribution across the country, its botanical characteristics and population structure. Due to financial constraints and limited staff, this should involve collaboration with third parties, including community forest groups as provided for in the Forest Act 4/2015 and SI 11/2018 (and as established also in the Southern African Development Community (SADC) Protocol on Forestry, e.g. art.9). Preliminary studies should be conducted to ensure the proper identification of targeted - potentially lookalike - species.

Recommendation: The Government of Zambia, and in particular its CITES Management and Scientific Authorities, should (i) seek to list mukula in Annex II; or (ii), as a preventive and more expedient measure, consider listing mukula in Annex III. This latter measure can be taken unilaterally and, although not as strong as listing in Annex II, will nonetheless send a signal to the international market that risk is high. To achieve this goal, the CITES Authorities of Zambia should seek (i) technical and political supports from the other African Parties of the natural distribution areas of the mukula species and (ii) financial assistance from any concerned Parties. Both Senegal (Pterocarpus erinaceus, Appendix II) and Gabon (Guibourtia spp., Appendix II) could assist Zambia in this process. Attention should be paid to species identification problems.

Recommendation: The Forestry Department, with the assistance of national and international academia, research institutions, and technical partners should investigate the impact of the mukula harvesting on the forest where it occurs. Protected areas should be given the closest attention.

Recommendation: The Forestry Department should be equipped with enough financial and human resources to implement the Forest Act of 2015 in a meaningful manner.

\section{Finding 4: The fast-evolving unique business model of the mukula trade presents significant challenges to the existing state-centered forest governance regimes.}

The business structures and models applied to mukula are largely unrelated to - and indeed unconstrained by - established national borders and regulations. They are 'fluid' in nature and easily move across borders if need be. In Zambia's case, the search for mukula and rosewood more generally has spread across neighboring countries such as the DRC, Mozambique and Malawi over a short period, wreaking havoc on those countries' natural capital.

All this creates new challenges for national governments and the international community in promoting rural development and sustainable use of natural resources such as land, timber and minerals. Such a 'globalized' rural informal economy urgently calls for innovative policies. These should maximize the benefits of global capital flowing directly to rural populations and minimize the negative impacts associated with the environment, revenue losses and resource governance.

Recommendation: In line with art.18 of the SADC Protocol on Forestry, the Government of Zambia should initiate and promote discussions within the appropriate bodies of the SADC, the East Africa Community and the Economic Community of the States of Central Africa, aimed at adopting (i) integrated timber market monitoring systems; and (ii) a rapid response team providing urgent policy options applicable to member states.

Recommendation: At national level, the Timber Producers' Association of Zambia should take a more pro-active role and support the Forestry Department in monitoring the removal and movement of timber in the country. This will also improve monitoring at the concession level, with direct positive benefits on environmental impacts.

In conclusion, and broadly speaking, findings speak to a powerful dynamic that was once exceptional but is becoming more common across sub-Saharan Africa. Existing national laws and under-resourced government agencies have proven insufficient to contend with fast-spreading, spatiallydisconnected and capital-intensive business models. While Zambian forests were emptied of 'rosewood' and the Zambian government was still deliberating potential countermeasures, buyers and traders had already started harvesting the forests of Malawi, the DRC and Mozambique, with containers leaving from Mombasa, Dar es Salaam, Beira, Durban and Walvis Bay.

Domestic solutions are bound to fail where similar commodities can be used, before even national laws realize that something is wrong in the national forests. International agencies (e.g. INTERPOL, IUCN), laws (e.g. US Lacey Act), regulations (e.g. EU Timber Regulation, Customs) and conventions (e.g. CITES) exist that can and do help in the effort. But, as our findings reveal, what is necessary first and foremost is a better regional, supranational integration of sub-Saharan countries where those commodities can be found and harvested. Unless that is done, countries will keep perfecting their own laws, only to find that implementation is useless because the resource is already gone and fragile forests irreparably damaged.

The mukula value chain illustrates the dysfunctional, conflicting and politically charged management of Zambian forests, and the gap between theory and practice. Power hierarchies at all 
levels of the state and across borders try to benefit as much and as quickly as possible, ultimately hampering the establishment of sustainable businesses. Because many operations in the timber export value chain need to be arranged well in advance, greater numbers of 'insecure' or 'unclear' elements or events in the chain render business riskier. These are not insurmountable barriers to doing business, as demonstrated by our results, but they increase the number of buyers and traders who are hesitant to make the kind of medium- to long-term investment that is needed for well-managed, sustainable and efficient forest sectors in Zambia and beyond.

\section{References}

Cook S, Weng X, Li M, Chen J, Xu B, Chen Y, Zhang J, Ren P, Wang L, Jones XH and Mayers J. 2018. Towards legal and sustainable investments by China in Africa's forests: Steps taken by Chinese organisations and the path ahead. London: International Institute for Environment and Development.

Cunningham AB. 2016. Trade study of selected east African timber production species. Bonn: Bundesamt für Naturschutz, Federal Agency for Nature Conservation.

[FEVCO] Forest and Environmental Vision Consultancy. 2007. Linking national forest programmes and poverty reduction strategies: Zambia. Lusaka: Food and Agriculture Organization of the United Nations, Forestry Department.

Huang W and Sun X. 2013. Tropical hardwood flows in China: Case studies of rosewood and okoumé. Bogor, Indonesia: Forest Trends, Center for International Forestry Research and World Agroforestry Centre.

Lwaile M and Gumbo DJ. 2016. Integrated land use assessment phase II - Technical paper 6: Measuring the informal forestbased economy as part of the national forest monitoring and assessment. Lusaka: Ministry of Lands, Natural Resources and Environmental Protection, Food and Agricultural Organization of the United Nations, Ministry of Foreign Affairs Finland.

Puustjärvi E, Mickels-Kokwe G and Chakanga M. 2005. The contribution of the forest sector to the national economy and poverty reduction in Zambia. Lusaka: Forestry Department, Zambia and Ministry for Foreign Affairs of Finland.

\section{Additional reading}

Cerutti PO, et al. 2018. Informality, global capital, rural development and the environment: Mukula (rosewood) trade between China and Zambia. London and Lusaka: International Institute for Environment and Development and Center for International Forestry Research.

\section{Acknowledgement}

This work was supported by the UK Economic and Social Research Council and the Department of International Development through the project "Natural Resources, Rural Poverty and China-Africa Trade: Equity and Sustainability in Informal Commodities Value Chains" [ES/M00659X/1] and Danida (Denmark), Irish Aid and Sida (Sweden). It is also part of the CGIAR Research Programme on Forests, Trees and Agroforestry (FTA), with support from the CGIAR Fund Donors: www.cgiar.org/our-funders. The full report on which this Infobrief is based can be downloaded from https://www.cifor.org and https://www.iied.org. The views presented in this publication are those of the authors and do not necessarily reflect the views of DFID, ESRC, CIFOR, CGIAR, Danida, Irish Aid or SIDA.

\begin{tabular}{|l|l|l|}
\hline RESEARCH & $\begin{array}{l}\text { The CGIAR Research Program on Forests, Trees and Agroforestry (FTA) is the world's largest } \\
\text { PROGRAM ON } \\
\text { Forests, Trees and } \\
\text { research for development program to enhance the role of forests, trees and agroforestry in } \\
\text { sustainable development and food security and to address climate change. CIFOR leads FTA in } \\
\text { partnership with Bioversity International, CATIE, CIRAD, ICRAF, INBAR and TBI. }\end{array}$ \\
CGIAR & $\begin{array}{l}\text { Agroforestry } \\
\text { C. }\end{array}$
\end{tabular}

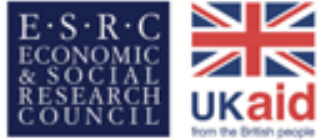

Revearos pondy spporsed by the EshC und DHD

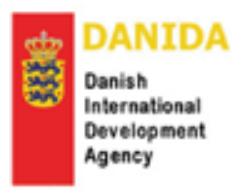

\section{Irish Aid}

Rialtas na hÉireann Government of Ireland

\section{乡\$ Sida}

